\title{
Foreign investment in Indonesia The Legal Aspects under the New Indonesian Investment Law
}

\author{
Petra Bunawan \\ Notary, Official Certifier of Title Deeds, Bandung, Indonesia \\ petrabunawan@gmail.com
}

Submitted: 2017-03-10; Reviewed: 2017-04-18; Accepted: 2017-05-26

\begin{abstract}
This article will give a slighty perspective according to Indonesian Investment law and other supportive law, both national and international. Indonesia plays an important role in the ASEAN region as well as in the global community, therefore investment policy become one of the major concern to government. To meet and accomodate the business enviroment both domestic and overseas that need capital investment, thus to develop the economic growth and build a suistainable economic stability in the region as well as for the people of Indonesia, it is neccessary to stipulate the inevestment law that provide all the need. Therefore the government has replaced the old law with the new Investment Law, the law No 25 of 2007. The Law provides the basic principle of legal certainty, non discrimination and same treatment for investors both domestic and overseas. The principles of opennes, accountability, togetherness and the concept of repatriation support the friendly investment atmosphere in Indonesia. As well as the supportive fasilities and easy procedure for investors to invest and build business in Indonesia. One of important issues regarding to Investment law is to increase the direct investment, instead of indirect investment that its contribution has a difference impact to the real sectors and economic growth.The question is the law and supportive law accomodatively provides the need of investment enviroment, knowing the economic growth has been influenced by the era of globalization and in fact Indonesia has signed and ratified international agreement as well.
\end{abstract}

Keywords: Foreign Investment; Legal Aspect; Investment law

\section{INTRODUCTION}

Indonesia is one of the sophisticative and attractive country. Facts that Indonesia is one of the global influence with a startegic location. Lies in the intersection of the Pacific Ocean and the Malaca Ocean, Indonesia plays a major role in ASEAN as well as in global affairs. the Standard
Chartered projecting Indonesia's economy could be the 10th largest in 2020 and the 5 th largest in $2030^{1}$.

Being a leading member of ASEAN , Indonesia has shaped integrative approaches in the region for security,trade and commerce and will be in the integral part of the ASEAN Economic Community

\footnotetext{
${ }^{1}$ www.bkpm.go.id
} 
in 2015. Indonesia is an attractive palce for for investors to build their business in variety sectors. Many sucessfull stories ,prove Indonesia's investment enviroment creates sucssesfull businessman in the ASEAN Region as well as in the world .

With the GDP expected to reach US\$ 1 trillion this year, Indonesia is the largest economy in Southeast Asia. Much less affected by the global financial crisis compared to its neighboring countries, Indonesia's economy grew by $6.3 \%$ in the first semester of 2012, making it the fastest growing G20 economy after China. The Indonesia economic success is a result of prudent fiscal stewardship that focused on reducing the debt burden ${ }^{2}$.Hence, due to the fact that Indonesia is now one of economically strong country, as well as politically stable and reform minded andsignificantly, labor costs in Indonesia are the lowest among the 10 ASEAN countries.Indonesia is an emerging global powerhouse in $\mathrm{Asia}^{3}$.

Based on The Global Competitiveness Report 2009-2010, World Economic Forum Geneva, Switzerland 2010. Indonesia is on the 44 rank, according this surveyIndonesia's ranking in the GCI is stillbetter than Brazil, Russia and India 4 . Based on International Credit Ratings, Indonesia Snares Investment Grade according to Japan Credit Rating Agency (JCR) on August 2011 statement is BBB stable, described the Indonesia's suitainability economic growth oulook underpinned by solid domestic demand, alleviated public debt burden that resulted by prudent fiscal management and debt management policy . Moreover according to Standards and Poor;s on April 2012, the grade's rank raised become $\mathrm{BB}+$ positive . This reflects the continuing improvement of the governemnt's balance sheet and external liquidity and cautious fiscal management ${ }^{5}$.

Investment Coordinating Board of the Republic of Indonesia (BKPM) has managed to boost Indonesia investment by set up an accomodated policies and strategy. Such as enhancement of Investment Cooperation by managed:

a. Completing negotiations with ASEAN and partner countries, MoU with government institutions, and business institutions.

b. Improving coordination with line ministries on bilateral, regional, and multilateral issues to facilitate investment - friendly regulations.

c. Enhancing the socialization of bilateral, regional, and multilateral agreements to stake holders.

d. Enhancement of BKPM's Role in Deregulating and Debottlenecking Investment-Related Regulations

e. Launching of investment incentive regulations.

f. Improvement of negative investment list (DNI).

g. Facilitation of sectoral regulations (divestment in mining industry, renegotiation of contract of work).

h. Improvement of regulations on PPP in infrastruture.

i. Synchronization of local and national regulations. 
j. Improvement of role of Export and Investment Improvement team $(\mathrm{PEPI})^{6}$

Indonesia has improved the investment policy, by updated the law. According to the law, investment law redefines as capital investment. The definition is under the Law No 25 year2007. This paper will account the legal aspect of investment under the Law No 25 year 2007.

\section{DISCUSSION}

The Basic Principles and Objectives Capital Investment under the Law Number 25 of 2007.

The Government of The Republic Indonesia has recognized the important role of foreign capital investment, therefore since 1967, the Investment Law is governed by Law No 1 of 1967, as amended by Law Number 11 of 1970 . The law was enacted to encourage foreign investment participation in Indonesia economy, especially in the industrial sector,particulary in those areas where capital advanced technology and management skills are not yet available domestically ${ }^{7}$.

Furthermore, to develop suitanable economy in order to achieve the objective of accelarating national economic development and increasing the potential investment both from domestic and overseas, the government has stipulated the new Investment Law. The Law Number 25 year 2007 concerning the investment has replaced the Law Number 1 of 1967, which have already amendment with the Law No 11 of 1970.

Under this new law, investment become one of the primary source of Indonesia"s participation in the global economy era and as well as the participation in a variety of international ccoperations. Investment Law No. 25/2007 updated and redefines "capital investment" as all investments, whether by domestic or foreign investors, for the first time offering equal treatment to all investors. There is no longer a limit of 30 years on foreign investment permits, and gone is the provision in Law 1/1967 for there to be divestment. Additionally, the new law allows for the unimpeded reparation of capital $^{8}$. It creates an investment climate whose nature is conducive, promotive, legally certain, impartial and efficient. ${ }^{9}$

Accelerating national economic development is Indonesia'aim to increase the economic growth and strength as well as to realise Indonesian political and economic soveteignity. Hence the government prioritized to increase the potential of capital investment originating from both domestic and overseas. Involving the development of micro, small and medium-sized enterprises and cooperatives is one of the stategy to support the economic stability.

According to article (3) of Law No 25 of 2007, "investment shall be organized on the principle of: legal certainty, openness, accoutability, the equal teratment, togertheness, impartial efficiency, sustainability, enviromental friendly,

\footnotetext{
${ }^{8}$ www.bkpm.com

${ }^{9}$ Law Number 25 of 2007, concerning Investment

${ }^{6}$ Ibid. Sudargo Gautama, Indonesian Business Law, Bandung: Citra Aditya Bakti, 2002, p. 359
} 
independency, and balance of progress and national economic unity.

The first principle of the foreign investment that is stated under the article 3 of the Law Number 25 year 2007 is legal certainty. This principle points that any law-obidient country that lays the law and rules of law as the foundation in every policy and legal action in the field of investment ${ }^{10}$. Furthermore, it emphasizes the important of certainty in the legal aspect, especially in doing businesses for domestic and overseas investment, as well asthe interagency coordination between central and regional government creates the efficient bureaucracy, in the respect of supportng the highly competitive economic.Investors are guaranteed to have a supportive business climate and can have an easy, transparant permission regarding the business that is built in Indonesia,in the term of tax incentives, granting of land use rightsand other supportive policy to conduct a good place doing business in Indonesia.

Second, the principle of openness. It is meant the open community rights concept, that investors can obtain correct, honest, indiscriminative information concerning the investment activity. Every investor has the same degree of treament concerning having a qulify investment information. Third, the principle of accountability. It determines the activity and the final result shall be accountable to the community or people as the holder of the highest sovereignity of the country in accordance eith the rules of law. Fourth the principle of equal treatment without discriminating the country of origin. The concept depicts the indicriminative service based on the rules of law. Investors both domestically or overseas shall have the same treament and undifferentiated.

Fifth, the principle of togetherness. The concept encourage the investors to take a role in the effort to realise people prosperity.

Sixth, the principle of impartial efficiency. It is emphasizing the important of prioritising impartial efficiency. The objective is to realise the impartial, conducive and competitive business climate in the country. Seventh, the sustainability principle. This means that the development process shall be run systematically in order to secure the prosperity and progress of investment in all aspects of life for today and tomorrow. Eight, enviromental friendly principle. The government is very concern regarding the enviroment sectors, consequently the investment shall constructed by continuesly consideringand prioritising the protection and presevervation the enviroment.

Ninth, independency principle. This principle underlying the important in focusing and emphasizing the nation and state potential domestic investment in line affords an opportunity the entry of foreign investment considering the economic growth realisation. Tenth, the principle of balance of progress and national economic unity. It meant that the investment sectors shall maintain the balance of regional economic progress within the national economic unity. The concept tries to integrate the development and growth of both regional and national economic.

The objectives of principles above is to;

${ }^{10}$ The eludation on the Law Number 25 of 2007 
1. Increasing national economic growth

2. Creating job opportunity

3. Improving sustainable economic development

4. Improving competitiveness of national business sphere

5. Increasing the capacity and the capability of national technology

6. Encouraging people econoic development

7. Processing economic potential into the real economic strength by using fund coming from both domestics and foreign counries

8. Improving the properity of the community ${ }^{11}$.

\section{Foreign Capital Investment Policy.}

Government stipulate the basic policy to conduct an atrractive capital investment. The objective is to encouraging the creation of conducive national business climate and accelerating the increase of investment, furthermore to realise the policy, of the same treatment both for the domestic and foreign investment, the government provides the opportunity for the development and protection to micro, small, medium -sizes, enterprises and ccoperatives.

The law Number 25 of 2007,defines investor shall any individual or corporation that makes investment in form of either domestic or foreign investors (article 1 (4)). In line with the article 1 (5), mentioning foreign investor shall any individual foreign citizien, foreign corporation or foreign state making investment within the territory of the Republic of Indonesia. In accordance of the foreign investment, the law states that the foreign capital shall any capital owned by any foreign country, foreign citizen, foreign corporation, foreign legal entity,and or Indonesian legal entity whose capital isowned partially or entirely by foreign party.

The investors will have a beneficial treatment concerning the establishment of the company in Indonesia. According to article (7), "the government shall neither nationalise nor take over the ownership right of any investors, except through the law and in the event that government does it, the government is required to pay compensation whose amount is stipulated based on market price.

Furthermore, the Law provides the right to make transfer and repatriation concept. According to article (8), investors have the right to:

1. Transfer their assets to another party they choose in acordance with the rules of law;

2. Any assests other than those set forth in paragaph (1) shall constitutes assets owned by the state as stipulated by the law;

3. To make transfer or repatriation in foreign currency to, among others:
a. Capital;
b. Profit,bank interest, dividend, and any other revenue;
c. Funds required for:
1) Purchasing raw materials and support materials, intermediate product or final product;

\footnotetext{
${ }^{11}$ Article 3 (2) Law Number 25 of 2007, concerning Investment
} 
2) Reimbursement of capital goods in order to secure investment.

d. Additional fund required for financing investment;

e. Fund for loan repayment;

f. Payable royalty interest;

g. Income of any foreign individuals working in any investment company;

h. The proceeds of any sale or liquidation of investment;

i. Compensation of any loss;

j. Compensation of any takeover;

k. Payment made for technical aid, payable costs for tehnical service and management, payment made under project contract, and payment for intellectual property right; and

1. Proceeds of asset sale set forth in paragraph (1).

The rights that is stated above shall be conducted in accordance with the rules of law. The law provides foreign capital investment to have the same treatment right to any investors originating from any countries whose making investment in Indonesia. It also provides the various assurances of :

1. Forming the limited liability company based on Indonesian Law

2. Having the shares when such compay is established

3. Purchasing the shares and;

4. Executing any other way pursuant to the rules of law ${ }^{12}$.

Besides the Investment Law, there are other laws that investors is obliged to incoporate an Indonesian P.T or Limited
Liability Company, now falling under the Law number 40 of 2007, that replacing the Law number 1 of 1995, and to have its legal seat within the territoy of Indonesia and government regulations that stipulating the investment in Indonesia. such as the government regulation number 77 of 2007 , concerning the List of Business closed and the List of Business opened to Investment and the government regulation number 111 of 2007 concerning the amendment to regulation of President of Republic of Indonesia number 77 of 2007,concerning the listof business closed and list of business oponed with reservation in the investment sector.

To form a limited liability company, foreign investors need to oblige the requirements that is stated in the Law Number 40 of 2007, concerning of The Limited Liability Company. the Law requires at least two persons as the founder of the company, and can consist of individual or a body corporate/legal entity.The steps to incorporate a Limited Company in Indonesia, known as P.T (Perseroan Terbatas) are; execute the deed of company's article association and other information related to the establishment of the company before the notary and obtain the status of legal entity form The Ministry of Law. The Law Number 3 of 1982, concerning the Obligation to Register the Company, intend that every company has the obligation to register their company ${ }^{13}$. Therefore, after obtained the P.T legal entity certificate, the company has to be registered in the Company Registry that is maintained by the Ministry of Industry and Trade. 
The limited liability company that is established by the foreigners, namely PMA (foreign investment company), has to apply a recomendation from the BKPM ((The Coordinating Investment Board)prior to establish the Limited Company. The BKPM will assist the foreign investors to get the investment information. Hence, the government provides a very comfortable and easy way for foreigners who want to start doing business in Indonesia.

The law provide variety rights and obligation for the investors. According to article (14), every investor shall entitled to obtain:
a. Right certainty;
b. Legal certainty
c. Protection certainy;
d. Open information about business fields
e. Service, and
f. Various forms of faciltiy according to the rules of law ${ }^{14}$.

Investors oblige to fullfill the requirement to:

a. Apply the principle of good company management

b. Implement the company's social responsibility

c. Make report on investment activity and submit it to the investment coordinating board

d. Repect cultural tradition of communities around the location of investment business activity

e. Comply with all the rules of law ${ }^{15}$.

Concerning the liability, investors are liable to :

\footnotetext{
${ }^{14}$ Article (14) Law No 25 of 2007

${ }^{15}$ Article (15) Law No 25 of 2007
}

a. Secure capital origanting from any sources not in violation with the rules of law

b. Bear and settle any obligations and losses if such investor halt or leave or abandon its business activity unilaterally in accordance with the rules of law

c. Create healthycompetitive business climate, refrain from monopy practice, and other matters that inflict damage of state

d. Preserve the enviroment

e. Provide safety, health, convinience and prosperity to workers

f. Comply with all the rules of law ${ }^{16}$.

The Law give the investment facilty, for those who expand its business and make a new investment. To receive the facilities, investors has to fulfil at least one of the following criteria:

a. To employ plenty workers

b. Belonging to high priority scale

c. Belonging to infrastructure development

d. Pioneering new industry

e. Transferring technology

f. Domiciling in remote area, deserted area, border area or any other area deemed necessary

g. Preserving enviroment

h. Conducting research, development and making innovation

i. Making partnership with micro, small and medium sized enterprises or cooperatives

j. Using capital goods or machinery or equipment produced domestically

\footnotetext{
${ }^{16}$ Article (16) Law No 25 of 2007
} 
The facilities given may be form of:

a. net income tax deduction up to certain level of investment made within certain period;

b. import duty holiday or reduction for imported capital goods, machinery, or equipment domestically unavailable for production;

c. import duty holiday or reduction for raw materials or support materials for production within certain period and with certain conditions;

d. value added tax holiday or postpenement for imported capital goods or machinery or equipment domestically unavailable for production within certain period;

e. accelerated deprecition or amortisation;

f. property tax reduction, especially for certain business fields in certain region, area or zone.

The government also provide the additional facilities by giving the convinience service and lincencing to investment company in obtaining:
a. land rights;
b. immigration service facility;
c. import licencing facilty.

Land Rights Permit for Investors according to article 22 states that Ease of land permit can be extended and renewed upon request of investors in form of:

a. Leasehold, may be given for 95 years and simultaneously renewed in advanced for 60 years and it may be further renewed for 35 years;

b. Building rights may be given for 80 years and simultaneously renewed in advanced for 50 years, and it may be further renewed for 30 years;

c. Rights to Use may be given for 70 years and simulataneously renewed in advanced for 45 years and may be further renewed for 25 years.

The renewal of the land rights is based on the condition, nature and objective of granting such rights and may be halted or annuled by the government if the investment company abandons the land, inflicts damage to public interest, uses the land in violation with the purpose and objective of such granting the rights. Licencing convinience may be given for any investment requiring foreign workers for realising the investment, as well as those workers in anture is temporary repairing machinery and other production support. The licencing shall be granted after such investor has been recommended by the BKPM (Investment Coordinating Board). The facilities granted for foreign investment are as follow:

a. Limited residential permit for two years for foreign investors

b. Change status form limited residential oermit into permanent residential permit after living in Indonesia for two consecutive years

c. One-year re-entry permit will be granted for several trips to any holders of limited residential permit that will apply for twelve months starting from the day such limited residential permit is granted

d. Two -year re-entry permit will be granted for several trips to any holders of limited residential permit that will apply for 24 months 
starting from the day such limited residential permit is granted

e. Re-entry permit will be granted for several trips to any holders of permanent residential permit that will apply for 24 months starting from the day such permanent residential permit is granted.

Those permit will be done by the Directorate General of Immigration based on recommendation of the Investment Coordinating Board

The Criteria and Establishment of Closed Business Field and Open Business Field with Conditions.

Business field that strictly closed for foreigners are production of weapons, ammunition, explosive equipment and warfare equipment. On the other hand the law provide the business filed that is opened with certain conditions based on the criteria of national interest and the protection of natural resources and protection of the small and medium enterprises.

To support the domestic and foreign investment, and to implement the Law Number 25 of 2007 concerning the Investment Law and the Presidential Regulation Number 77 of 2007 on the list business closed and open with conditions investment, as well as to increase investment activities in Indonesia and for the purpose of implementing Indonesia's commitment with the respect to the Association of Southeast Asian Nations/ASEAN Economic Community (AEC), the government rework the provision of the list business field closed and open with conditions with the new

${ }^{17}$ Government Regulation Number 36 of 2010.
Government Regulations Number 36 of $2010^{17}$.

Based on the Government Regulation, a closed business field is a certain business that are prohibited from conducting any investment activities (article 1). The business field open with conditions are certain business field that may conduct investment activities under particular requirements, such as;

1. Licensed businesses reserved for Micro, Small and Medium Enterprises and;

2. Cooperatives, licensed businesses requiring certain capital ownership;

3. Licensed businesses requiring a certain location ;

4. Licensed businesses requiring special permit. ${ }^{18}$

The investment in business open field must meet requirementsof location and in line with the regulaitons applicable in spatial and enviroment sectors. Thus in the case of businees fields open, it has been determined that the investor is willing to extend the businessby engaging in the same business activities outside the location determined in the investment licence. In order to meet hte requirement of location, the investors are not obliged to establish new business entities or obtain new business licenses, except stipulated by the law.

Furthermore, in the case that a change occurs to capital ownership as a result of merger, acquisition, or amalgamation of a company enganged in the same business field, the regulation stipulated that;

1. a limitation of capital ownership from a foreign investment in the

${ }^{18}$ Ibid, Article (2) 
meging company shall be as set out in the approval letter of the company;

2. a limitation of capital ownership; from a foreign investment in the acquring company shall be set out in the approval letter of the company;

3. a limitation of capital ownership from a foreign investment in a new company resulting from an amalgamation shall be complience with the provisions applied when the company was formed from that amalgamation.

There are some restrictions for foreign investor that want to expands the business and requires additional capital through a rights issue and domestic investors are unable to participate in the said additional capital, then requirements of right issues will be applied for domestic investment, in accordance iwth the law and regulations in the sector o limited liability company 19 .

In the event that a foreign investor expands his business activities in thesame business sector, according to article (6) The Presidential Regulation, foreign investors that need requiring additional capital through a rights issueand on the other hand domestic investorsare unable to participate in the said additional capital, then requirementsof right issues will be applied for domestic investment, in accordancewith the laws and regulations in the sector of a limited liability company.the presidential regulation provides that if as a result intotal ownership of foreign capital to exceed the maximum limit set out inthe Approval Letter, then within a period of two (2) years, the exceedingtotal ownership of foreign capital investment may be adjusted from theminimum limit included in the approval letter, by means of:

a. the foreign investor sells the excess of shares in good will todomestic investor;

b. the foreign investor sells the excess of shares through a generaltender conducted by a company whose shares are owned bythe foreign investor in a domestic capital market; or

c. the companypurchases the excess shares owned by the foreign investor andtreats the shares as treasurystocks, subject to Article 37 of Law Number 40 of 2007 on Limited Liability Company. ${ }^{20}$

The objectives to regulate and establish the closed business line and open business line with condition, based on the Presidential Regulation Number 76 of 2007 are:

1. To place a secure legal foundation for the drafting process of the regulation that is relevant to capital investment;

2. To ensure transparency in the listing process of closed business lines and open business line with conditions;

3. To provide a guidance in preparing and establishing the closed business lines and open lines business with conditions;

4. To provide a guidance in reviewing the list of closed business lines and open business line withconditions; 
5. To provide a guidance shall different interpretation occurs on the list of closed business lines and open business line with conditions $^{21}$

Furtermore, the regulation apply the basic principles, such are;

1. Simplification

2. Compliance to international agreement or commitment

3. Transparency

4. Legal certainty

5. Unity of Indonesian territory as a singel market.

The principle of simplification intends to prevail nationlly in simple manner and limited to the business line that is relevant to national interest and forms a small part of the overall economy and small part of every sector in economy and business lines declared closed and open with conditions has to comply with the international agreement which shall not contradicts Indonesia's obligations as stipulated in the ratified international agreement.

Tranperancy principle aim is to give a clear, detailed and do not cause multi interpretation, therefore the objective is to provide a legal ceertainty. As the business line declared closed nd open with conditions cannot changed except with a Presidential Regulation. The Principle of unity of Indonesian territory as single market shall not prevent the flow of goods, services, capital, human resources and information in the territory of the unitary Republic of Indonesia.

Based on the President Regulation, the business lines that are closed for capital investment both foreign and domestic are

${ }^{21}$ President Regulation Number 76 of 2007 determined on the basis of the following criteria, such as health, safety, national defence and security, enviroment, moral,culture and other interests. The criteria are;

1. Preserve the community's life structure;

2. Protect the biodiversity;

3. Maintain the balance of ecosystem;

4. The preservation of natural forest;

5. Supervise the use of dangerous chemicals;

6. Safeguard from fraud and the unploanned oversight/circulation;

7. Maintain state sovereignity ;

8. Protect and maintain limited resources.

Furthermore the criteria to establish open business line with conditions are;

1. The protection of natural resources;

2. The protection and development of micro, small, medium business and cooperatives;

3. The supervision of production and distribution;

4. The improvement of technological capacity;

5. The participation of domestic capital;

6. The cooperation with the business appointed by the government. ${ }^{22}$

The government provides the establishment of open business line with conditions based on the consideration of decent and feasible economy to protect Micro Small Enterprises (MSME), therefore are composed of protection and development of Micro Small Enterprises (MSME). The condition of partnership,

${ }^{22}$ Presindetial Regulation No 77 of 2007 
capital ownership, specified location and special permit. To support the development of domestic and foreign investment in Indonesia, the government has stipulated the Government Regulation number 36 of 2010, regarding to the open business line with conditions .

\section{Tax Policy for Certain Business Field}

The new investment especially for pioneering industries, that is any indutries possesing exensive connections, providing high value added and externalities, introducing new tecnology and possesing strategic value for national economy. according to article $(18)^{23}$, can receive company's income tax holiday or reduction within certain amount and period.

Thus, supporting the investment law that considering the direct investment as well as the non direct investment, both for domestic and foreign investment is one of important factors, that supporting economic growth, development, distibution and development acceleration for certain busines region. Therefore, the Government manages to provide an income tax facilities for investors in certain business field, by Government Regulation Number 1 of 2007 , regarding Income Tax for Investment in Certain Business Fields ${ }^{24}$.

Income Tax facilities as intended above shall be as follows:

a. $30 \%$ (thirty percent) net tax deduction of the total Investment, charged for 6 (six) years for $5 \%$ (five percent) annually; accelerated depreciation and amortization shall be as follows:

income tax charge for dividend paid to Foreign Tax Subject shall be 10\% (ten percent), or lower tariff according to effective Double Taxation Avoid Agreement; and loss compensation for more than 5 (five) years but not more than 10 (ten) years with the following provisions:

1) 1 year extra: in case the new investment in business field stipulated in Article 2 paragraph (1) item a is conducted in industrial estate and bonded zone;

2) 1 year extra: in case it hires at least 500.

Article (2), intended as follows:

(1) Taxpayer of domestic agencies in the form of limited company and cooperation investing on:

a. certain business fields as stipulated in Appendix I of this Government Regulation; or

b. certain business fields and certain regions as stipulated in Appendix II of this Government Regulation can be awarded Income Tax facilities.

(2) Income Tax facilities as intended in paragraph (1) above shall be as follows:

a. $30 \%$ (thirty percent) net tax deduction of the total Investment, charged for 6 (six) years for $5 \%$ (five percent) annually;

b. accelerated depreciation and amortization shall be as follows: 


\begin{tabular}{|l|c|c|c|}
\hline \multicolumn{1}{|c|}{$\begin{array}{c}\text { Tangible Fixed } \\
\text { Assets Group }\end{array}$} & $\begin{array}{c}\text { Benefit } \\
\text { Period } \\
\text { Becomes }\end{array}$ & \multicolumn{2}{|c|}{$\begin{array}{c}\text { Depreciation and Amortization } \\
\text { Tariff Based on Method }\end{array}$} \\
\cline { 3 - 4 } & & Straight Line & $\begin{array}{c}\text { Decreasing } \\
\text { Balance }\end{array}$ \\
\hline I. Non Building: & 2 years & $50 \%$ & $100 \%$ \\
Group I & & $25 \%$ & $\begin{array}{c}\text { once) } \\
\text { (charged all at }\end{array}$ \\
Group II & years & $12,5 \%$ & $50 \%$ \\
Group III & 8 years & $10 \%$ & $25 \%$ \\
Group IV & 10 years & $10 \%$ & $20 \%$ \\
II.Building: & 10 years & $20 \%$ & - \\
Permanent & 5 years & & - \\
Non-Permanent & & & \\
\end{tabular}

c. income tax charge for dividend paid to Foreign Tax Subject shall be $10 \%$ (ten percent), or lower tariff according to effective Double Taxation Avoid Agreement; and

d. loss compensation for more than 5 (five) years but not more than 10 (ten) years with the following provisions:

1) 1 year extra: in case the new investment in business field stipulated in Article 2 paragraph (1) item a is conducted in industrial estate and bonded zone;

2) 1 year extra: in case it hires at least 500 (five hundred) Indonesian work forces for 5 (five) consecutive years;

3) 1 year extra: in case the new investment requires investment/cost for economic and social infrastructure in business location minimum Rp.10,000,000,000.00 (ten billions Rupiah);

4) 1 year extra: in case domestic research and development costs for product development or production efficiency at least $5 \%$ (five percent) from investment for 5 (five) years period; and/or

5) 1 year extra: in case it uses raw materials and or domestic products at least $70 \% \quad$ (seventy 
percent) since the fourth year.

Furthermore the article (3), stated that Taxpayers receiving facilities as referred to in Article paragraph (2) before 6 (six) years since date of facilities delivery may not:

a. use fixed assets receiving facilities for any objectives other than awarded by the facilities; or

b. transfer parts or all fixed assets receiving facilities but the transferred fixed assets are changed with new fixed assets.

\section{CONCLUSION}

Being one of the destination country in the investment enviroment as well as shaped integrative approaches in the region for security,trade and commerce. Nevertheless Indonesia will be in the integral part of the ASEAN Economic Community in 2015 as well as in the world. Indonesia stipulated The Indonesian Investment Law. it provides the easiness, simplicity and supportive facilities to attract investors both domestic and overseas. Thus, the principle of same treatment both for domestic and foreign investors accomodate the need of openness, transparant and conducive business enviroment in Indonesia, not only for the sake of the people of Indonesia, even for the global community in the world.

\section{BIBLIOGRAPHY}

\section{Books}

Sudargo Gautama, Indonesian Business Law, Bandung: Citra Aditya Bakti, 2002.

\section{Regulation}

Law Number 25 of 2007 on the Investment Law

Law Number 40 of 2007 on the Limited Liability Company

Law Number 3 of 1982 on Registering Company

Law Number 13 of 2003 on Man Power Law

Presidential Regulation Number 77 of 2007 on the closed business line and open business line with condition

Presidential Regulation Number 36 of 2010 on the closed business line and open business line with condition, based on the Presidential Regulation Number 76 of 2007

Presidential Regulation Number 36 of 2010 of list of business fields closed to Investment and busiess fields open with conditions

Government regulation number 111 of 2007 concerning the amendment to regulation of President of Republic of Indonesia number 77 of 2007, concerning the list tof business closed and list of business oponed with reservation in the investment sector.

Government Regulation No 1 of 2007, concerning Income Tax for Investment in Certain Business Fields.

\section{Online Reference}

www. BKPM. 